\title{
PENGARUH PEMBERIAN REBUSAN AIR JAHE TERHADAP LOW BACK PAIN PADA PEKERJA PEMBUAT BATU BATA
}

\author{
IKA NUR SAPUTRI ${ }^{1}$, IRMA NURIANTI ${ }^{2}$, M. RIDUWAN ${ }^{2}$ \\ ${ }^{1}$ Fakultas Kebidanan Institut Kesehatan Medistra Lubuk Pakam \\ ${ }^{2}$ Fakultas Kesehatan Masyarakat Institut Kesehatan Medistra Lubuk Pakam \\ Jl. Sudirman No 38 Lubuk Pakam \\ e-mail: ikanursaputri@gmail.com \\ DOI : https://doi.org/10.35451/jkg.v4i1.818
}

\begin{abstract}
Low Back Painis a musculoskeletal disorder which located at the lowerback, is caused by several of diseases and many of bad activities of the body. One of the non-pharmacological therapies that can be used in reducing the low back pain'ssuffer of the patients is ginger water. This research aimisto find out the effect of ginger waterto decrease pain intensity in the low back pain patient. This researchis pre-experimentalwith the design of the pre-testand post-test one group design. The research design used a research design with a quasiexperimental or quasi-experimental approach. The population in this study were 35 workers who made bricks and sample taken using a total sampling that was 35 workers. Data collection methods were primary data and secondary data. The data analysis used was univariate analysis and bivariate analysis. The results showed the $p$ value $=0.000$, with a degree of error $(a)=5 \%, p$ value $<0.05$, which means that there is an effect of giving boiled ginger water on low back pain in brick-making workers in Beringin District in 2021. The conclusion shows that there is an effect of giving boiled ginger water on low back pain in brickmaking workers in Beringin District in 2021. It is suggested that brick workers can make ginger boiled water as a method to reduce complaints of low back pain.
\end{abstract}

Keywords: Ginger Water Stew, Low Back Pain.

\section{Pendahuluan}

Penyakit Akibat Kerja (PAK) dapat disebabkan oleh hubungan kerja atau pekerjaan dan sikap kerja. Penyakit akibat kerja yang disebabkan oleh pekerjaan dapat dipengaruhi oleh peralatan, material dan lingkungan kerja. sementara itu, penyakit akibat kerja yang disebabkan oleh sikap kerja dapat dipengaruhi oleh posisi yang tidak ergonomis dan lamanya jam kerja duduk atau berdiri dalam waktu yang cukup lama, Low Back Pain (LBP) merupakan suatu sindroma klinik yang ditandai dengan gejala utama adanya rasa nyeri atau perasaan tidak enak di daerah tulang punggung bawah. (Low Back Pain) (Natosba \& Jaji, 2015).

Berdasarkan data yang diperoleh dari survey work-related disease di inggris menunjukkan bahwa dari perkiraan 43.000 pekerja di sektor pembuatan batu bata terjadi gangguan ergonomis dengan rincian kasus back pain injury pada keluhan keluhan pada lower limb injury pada 11.000 pekerja pembuat batu bata. sangat mudah mengalami yang namanya Low Back Pain (LBP) dari pada pekerja yang mempunyai aktivitas yang tidak terlalu sukar (Payuk, 2013). 
Menurut WHO menunjukkan bahwa terdapat 2\%-5\% dari pekerja atau karyawan di Negara bagian industri setiap tahunnya merasakan nyeri low back pain (LBP) dan $15 \%$ dari abstenteisme pada industri baja dan industri bagian perdagangan disebabkan karena LPB, data statistik di Amerika serikat memiliki angka kejadian sebanyak $15 \%-20 \%$ tiap tahun, terdapat $90 \%$ kasus nyeri low back pain yang penyebabnya bukan karena kelainan organic, tetapi disebabkan oleh karena posisi tubuh saat bekerja yang tidak benar (WHO, 2014).

Dari data epidemiologi mengenai Low Back Pain (LBP) di Indonesia, tidak diketahui secara pasti, namun diperkirakan penderita Low Back Pain (LBP) di Indonesia bervariasi antara 7,6$37 \%$ dari jumlah penduduk yang ada di Indonesia (Lailani 2013). Dan data mengenai jumlah penderita Low Back Pain (LBP) di kota medan diperoleh di dua rumah sakit, data dari RSU Sundari Medan Sumatra Utara di tahun 2015 menunjukkan terhadap 280 kasus yang terjadi jumlah kasus LBP tertinggi terjadi pada bulan Desember sebanyak 72 kasus (Armiza, 2018). Sedangkan melalui survey yang didapatkan dari Rumah Sakit Umum Daerah (RSUD) Dr. Pringadi Medan Sumatra Utara pada periode Januari-Desember 2016 sebanyak 1295 penderita (Limbong, 2017).

Low Back Pain (LBP) adalah suatu periode nyeri di punggung bawah yang berlangsung lebih dari 24 jam, yang didahului dan diikuti oleh 1 bulan atau lebih tanpa nyeri punggung bawah. sumber lain menyebutkan LBP adalah nyeri dan ketidak nyamanan yang terlokalisasi di bawah sudut iga terakhir (costal margin) dan diatas lipat bokong bawah dengan atau tanpa nyeri pada daerah tungkai, LBP termasuk salah satu dari gangguan akibat dari mobilisasi yang salah.

\section{InternationalLabour}

Organization(ILO)

(Umami2014) menyebutkan bahwa ketenaga kerjaan informal adalah seluruh jenis pekerjaan yang memberikan pendapatan, baik pekerjan mandiri dan pekerjaan dengan gaji, yang tidak diakui, diatur atau dilindungi oleh Hukum dan peraturan yang ada pelayanan kesehatan bagi pekerja sektor informal pada saat ini belum sesuai dengan beratnya pekerjaan yang dilakukan, sehingga pekerja rentan mengalami masalah-masalah kesehatan seperti akut antara lain, sakit gigi, pusing, patah tulang dan luka bakar.Low Back Pain non spesifik merupakan gejala tanpa penyebab spesifik yang jelas. Sekitar $90 \%$ nyeri pinggang masuk dalam kategori ini. Diagnosisinya berdasarkan ekslusi dari patalogi spesifik. Koes et al. (2015).

Sedangkan berdasarkan survey pada pekerja pembuat batu bata di Desa Sidourip Kecamatan Beringin Kabupaten Deli Serdanng Tahun 2021 di dapatkan Responden mengalami nyeri LBP, diketahui bahwaDari 35 pekerja ditemukan 15 pekerja mengalami nyeri Low Back Pain dari skala 6-8, Hal ini menunjukkan bahwa sebagian besar pekerja batu bata mengalami LBP.

faktor resiko terjadinya low back pain menurut (Andini, 2015) sebagai berikut, Usia seiring bertambahnya usia akan terjadi degenerasi tulang dan keadaan ini mulasi terjadi saat usia mencapai kisaran 30-40 tahun, jenis kelamin juga termasuk resiko mengalami low back pain dimana prevelensi terjadi nya LBP lebih banyak terjadi pada wanita dari pada laki-laki. Beberapa penelitian juga menyebutkan bahwa wanita lebih sering meminta izin untuk tidak masuk kerja karena LBP. Hal ini tersebut terjadi secara fisiologi karena kemapuan otot wanita rendah dari pada laki-laki.

Kandungan air jahe yang dapat mengurangi Low Back Pain berfungsi Secara umum, semua berbagai jenis 
jahe mempunyai kandungan dan zat yang sama kaya akan manfaat.Kandungan jahe pada umumnya terdiri atas air, serat, karbohidrat, protein, lemak, mineral, dan vitamin. Kandungan Beberapa jenis mineral yang ada di dalam jahe yaitu kalsium, fosfor, dan besi. Jahe mengandung berbagai jenis vitamin seperti vitamin $A$, vitamin B1 (tiamin), vitamin B3 (niasin), dan vitamin C. (Lase, 2015).

Air jahe yang digunakan berfungsi untuk melebarkan pembuluh darah, menstimulasi sirkulasi darah, dan mengurangi kekakuan. Selain itu, pemberian rebusan air jahe juga berfungsi menghilangkan sensasi rasa sakit. Untuk mendapatkan hasil yang terbaik, pemberian rebusan air jahe hangat diberikan 2 kali sehari pagi dan sore, dan mengukur intensitas nyeri setelah mengkonsumsi.

Selama ini belum pernah dilakukan terapi pemberian air jahe hangat pada pekerja pembuat batu bata oleh karna itu peneliti tertarik untuk melakukan penelitian dengan judul pengaruh pemberian rebusan air jahe terhadap low back pain pada pekerja pembuat batu bata.

\section{METODE}

Jenis Penelitian ini adalah penelitian kuantitatif dengan pendekatan quasi eksperimen atau eksperimen semu, Dimana kegiatan percobaan bertujuan untuk mengetahui suatu gejala atau pengaruh yang timbul, sebagai akibat dari adanya perlakuan tertentu. Rancangan penelitian yang digunakan adalah rancangan One Group pretestpostest,yaitu melakukan penelitian sekaligus memberikan perlakuan dan mengevaluasi perlakukan tersebut. Perlakuan berupa Pemberian rebusan air jahe dengan jumlah berat 200 gram yang sudah bersih dan di potong kecil-kecil kemudian di rebus dalam air sebanyak $500 \mathrm{ml}$, sampai tersisa menjadi $250 \mathrm{ml}$, di minum pagi dan sore setelah makan. Selama 14 hari atau 2 minggu.

\section{HASIL}

Berdasarkan tabel dibawah ini menunjukkan bawasannya karakteristik responden berdasarkan jenis kelamin laki-laki ada sebanyak 24 orang (68.6\%) dan jenis kelamin perempuan sebanyak 11 orang (31.4\%). Jika diliat dari usia responden 35-40 tahun ada sebanyak 20 orang $(57.1 \%)$, usia $>52$ tahun sebanyak 14 orang $(40.0 \%)$ dan usia $<35$ tahun sebanyak 1 orang (2.9\%).

Tabel 1 Karakteristik responden yang diamati meliputi jenis kelamin dan usia.

\begin{tabular}{|c|c|c|c|c|}
\hline $\begin{array}{l}\mathrm{N} \\
\mathrm{O}\end{array}$ & $\begin{array}{c}\text { Karakteris } \\
\text { tik }\end{array}$ & Kategori & $\begin{array}{c}\text { Frekue } \\
\text { nsi }\end{array}$ & $\begin{array}{c}\text { Presenta } \\
\text { se }(\%)\end{array}$ \\
\hline \multirow{3}{*}{1} & $\begin{array}{c}\text { Jenis } \\
\text { Kelamin }\end{array}$ & Perempu & 11 & 31.4 \\
\hline & & Laki-laki & 24 & 68.6 \\
\hline & Total & & 35 & 100 \\
\hline \multirow{4}{*}{2} & & $\begin{array}{l}<35 \\
\text { Tahun }\end{array}$ & 1 & 2.9 \\
\hline & Usia & $\begin{array}{c}35- \\
\text { 40Tahun }\end{array}$ & 20 & 57.1 \\
\hline & & $>52$ & 14 & 40.0 \\
\hline & Total & & 35 & 100 \\
\hline
\end{tabular}

Berdasarkan tabel 2.dibawah menunjukkan bawasannya low back pain pada responden sebelum diberikan rebusan air jahe yaitu dari rentang nilai 0- (tidak nyeri) Low back pain sebanyak 7 orang $(20.0 \%)$, dari rentang nilai $1-3$ (nyeri ringan) sebanyak 8 orang (22.9\%), dari rentang nilai 4-6 (nyeri sedang) sebanyak 14 orang ( $40.0 \%)$, dari rentang nilai 7-9 (nyeri berat) sebanyak 6 orang (17.1\%) dan tidak ada responden yang megalami low back pain dari rentang nilai 10 (nyeri sangat berat) dengan total responden sebanyak 35 $(100 \%)$.

Tabel 2. Distribusi Low Back Pain Sebelum diberikan Rebusan Air Jahe

\begin{tabular}{cccc}
\hline No & $\begin{array}{l}\text { Low Back } \\
\text { Pain(LBP) }\end{array}$ & Frekuensi & $\begin{array}{c}\text { Presentase } \\
(\%)\end{array}$ \\
\hline 1 & $\begin{array}{l}\text { 0 (tidak } \\
\text { nyeri) }\end{array}$ & 7 & 20
\end{tabular}




\begin{tabular}{clcc}
2 & $\begin{array}{l}1-3 \quad \text { (nyeri } \\
\text { ringan) }\end{array}$ & 8 & 22.9 \\
3 & $\begin{array}{l}4-6 \quad \text { (nyeri } \\
\text { sedang) }\end{array}$ & 14 & 40.0 \\
4 & $\begin{array}{l}7-9 \quad \text { (nyeri } \\
\text { berat) (nyeri }\end{array}$ & 6 & 17.1 \\
5 & $\begin{array}{l}10 \text { sangat } \\
\text { berat) }\end{array}$ & 0 & 0 \\
\hline Total & 35 & 100 \\
\hline
\end{tabular}

Berdasarkan tabel 3 dibawah menunjukkan bawasannya distribusi keluhan low back pain pada responden sesudah diberikan rebusan air jahe yaitu dari rentang nilai 0- (tidak nyeri) Low Back Pain sebanyak 13 orang (37.1\%), dari rentang nilai $1-3$ (nyeri ringan) sebanyak 16 orang $(45.7 \%)$, dari rentang nilai (nyeri sedang) sebanyak 6 orang ( $17.1 \%$ ), dan dari rentang nilai 7-9 (nyeri berat) sebanyak 0 orang ( $0 \%$ ). dan tidak ada responden yang megalami low back pain dari rentang nilai 10 (nyeri sangat berat) dengan total responden sebanyak $35(100 \%)$ orang.

Tabel 3. Distribusi Low Back Pain Sesudah diberikan Rebusan Air Jahe

\begin{tabular}{|c|c|c|c|}
\hline No & $\begin{array}{l}\text { Low Back } \\
\text { Pain(LBP) }\end{array}$ & Frekuensi & $\begin{array}{c}\text { Presen } \\
\text { tase }\end{array}$ \\
\hline 1 & $\begin{array}{ll}0 & \text { (tidak } \\
\text { nyeri) }\end{array}$ & 13 & 37.1 \\
\hline 2 & $\begin{array}{l}1-3 \text { (nyeri } \\
\text { ringan) }\end{array}$ & 16 & 45.7 \\
\hline 3 & $\begin{array}{l}4-6 \text { (nyeri } \\
\text { sedang) }\end{array}$ & 6 & 17.1 \\
\hline 4 & $\begin{array}{l}7-9 \\
\text { berat) }\end{array}$ & 0 & 0 \\
\hline 5 & $\begin{array}{l}10 \text { (nyeri } \\
\text { sangat berat) }\end{array}$ & 0 & 0 \\
\hline & Total & 35 & 100 \\
\hline
\end{tabular}

Berdasarkan tabel 4 di bawah menunjukkan bahwa analisis statistic dengan menggunakan uji one sampel Ttest nilai rerata skala nyeri low back pain pada pekerja pembuat batu bata sebelum pemberian air jahe adalah 4.34 dengan standart Deviasi (DS) yaitu 3.048 95\% Skor skala nyeri low back pain pekerja antara 3.30 - 5.39 dan sesudah pemberian air jahe 1.77dengan Standart Deviasi (SD) yaitu 1.816 95\% Skor skala nyeri low back pain pekerja antara 1.55
- 2.40. Dengan $P$ value 0.000 yang artinya ada pengaruh yang signifikan antara pemberian rebusan air jahe terhadap low back pain pada pekerja pembuat batu bata di Kecamatan Beringin tahun 2021.

\section{Tabel 4. Pengaruh Pemberian} Rebusan Air Jahe Terhadap Low Back Pain

\begin{tabular}{ccccc}
\hline $\begin{array}{l}\text { Skala } \\
\text { Nyeri }\end{array}$ & $\begin{array}{c}\text { Me } \\
\text { an }\end{array}$ & $\begin{array}{c}\text { Standa } \\
\text { rt } \\
\text { Devias } \\
\text { i (SD) }\end{array}$ & $\begin{array}{c}\text { St95\% } \\
\text { CI }\end{array}$ & $\begin{array}{c}\text { P } \\
\text { Value }\end{array}$ \\
\hline Sebelum & 4,3 & 3,048 & $3.30-$ & \\
Sesudah & 4 & & 5.39 & 0.000 \\
& 1,7 & 1,816 & $1.55-$ & \\
& 7 & & 2.40 & \\
\hline
\end{tabular}

\section{PEMBahasan}

Berdasarkan hasil penelitian yang dilakukan pada 35 responden pekerja pembuat batu bata di Kecamatan beringin sebelum diberikan rebusan air jahe dengan menggunakan alat ukur nyeri yaitu visual analoge scale (VAS) dengan rentang nilai 1-10 mendapatkan hasil bahwa low back pain sebelum diberikan rebusan air jahe yaitu dari rentang nilai 0- (tidak nyeri) Low back pain sebanyak 7 orang $(20.0 \%)$, dari rentang nilai $1-3$ (nyeri ringan) sebanyak 8 orang $(22.9 \%)$, dari rentang $4-7$ (nyeri sedang) sebanyak 14 orang $(40.0 \%)$, dari rentang 8-9 (nyeri berat) sebanyak 6 orang $(17.1 \%)$ dan dari rentang nilai 10 berjumlah $0(0 \%)$, (nyeri sangat berat) tidak ada responden yang mengalami Low back pain. Nilai rerata skala low back pain pada pekerja pembuat batu bata sebelum pemberian air jahe adalah 4.34 dengan standart Deviasi (DS) yaitu 3.048 95\% Skor skala nyeri low back pain pekerja antara 3.30 - 5.39 dengan total jumlah responden sebanyak 35 oarang.

Berdasarkan hasil penelitian yang dilakukan pada 35 responden pekerja pembuat batu bata di Kecamatan beringin mendapatkan hasil bahwa low back pain sesudah diberikan rebusan air jahe yaitu dari rentang nilai 0 (tidak 
nyeri) sebanyak 13 orang (37.1\%), dari rentang nilai $1-3$ (nyeri ringan) sebanyak 16 orang $(45.7 \%)$, dari rentang nilai $4-7$ (nyeri sedang) sebanyak 6 orang $(17.1 \%)$, dari nilai rentang 8-9 (nyeri berat) sebanyak 0 orang $(0 \%)$ dan dari rentang nilai 10 (nyeri sangat berat) tidak ada (0) penderita . Nilai rerata sesudah pemberian rebusan air jahe yaitu 1.77 dengan Standart Deviasi (SD) yaitu 1.816 95\% Skor skala nyeri low back pain pekerja antara 1.55 - 2.40 dengan total jumlah responden sebanyak 35 orang.

Keadaan ini dapat diterima karena peneliti mengasumsikan bahwa tanaman jahe mempunyai kegunaan yang cukup beragam, antara lain sebagai rempah, minyak atsiri, pemberian aroma, ataupun sebagai obat dan memiliki kandungan kimia seperti ginggerol, shogaol dan zingerone yang bermanfaat memberikan efek farmakologi dan fisiologi seperti antioksidan, antiflammasi, analgesic, antikarsinogenik, non-toksik dan nonmutagenik meskipun pada kosentrasi tinggi (bartley dan Jacobs,2000). Sehingga dengan mengkonsumsi rebusan air jahe dari bahan segar dan setiap hari akan menurunkan sakit otot akibat posisi kerja, lama berkerja dan lain-lain.

\section{KESIMPULAN}

1. Low back pain pada responden sebelum diberikan rebusan air jahe yaitu mengalami tidak nyeri Low back pain sebanyak 7 orang (20.0\%), dan Nyeri ringan low back pain sebanyak 8 orang $(22.9 \%)$, nyeri sedang low back pain sebanyak 14 orang ( $40.0 \%$ ), nyeri berat low back pain sebanyak 6 orang $(17.1 \%)$ dan tidak ada responden yang megalami nyeri sangat berat.

2. Low back pain pada responden sebelum diberikan rebusan air jahe yaitu mengalami tidak nyeri Low Back Pain sebanyak 13 orang (37.1\%), nyeri ringan low back pain sebanyak 16 orang
$(45.7 \%)$, nyeri sedang low back pain sebanyak 6 orang ( $17.1 \%)$, dan dan tidak ada responden yang mnegalami low back pain nyeri berat dan Low Back Pain nyeri sangat berat.

3. Dengan menggunakan uji one sampel $\mathrm{t}$-Test diperoleh nilai $\mathrm{p}$ value $=0.000(\mathrm{p}$ $<0.05$ ). Dapat disimpulkan bahwa "Ada pengaruh pemberian rebusan air jahe terhadap low back pain (LBP) pada pekerja pembuat batu bata di Kecamatan Beringin tahun 2021.

\section{DAFTARPUSTAKA}

Andini, F. 2015. Risk Factory of Low Back Pain in Workers. J Majority. Vol. 4 No.1. Januari 2015.

Armiza, Hubungan Indeks Massa Tubuh Dengan Intensitas Nyeri Punggung Bawah Pada Penderita Low Back Pain Yang berobat Di Rumah Sakit Sundari Tahun 2018, Skripsi Fakultas Kedokteran Universitas Sumatra Utara Medan 2018.

Bartlehey, J. And A. Jacobs. 2000. Effects of Drying on Flavour Compound in Australian-Grown Ginger (Zingiber officinale). Journal of the Science of Food and Agriculture.

Koes BW, Tulder MWV, Thomas $\mathrm{S}$. Diagnosis And Treatment of Low Back Pain. BMJ. 2006;332: 14304. 2015 .

Limbong, 2017, Falls Efficacy Pada Pasien Low Back Pain di Rumah Sakit Pringadi medan, Universitas Sumatra Utara.

Lailani, M.T. 2013. Hubungan Antara Peningkatan Indeks Massa Tubuh Dengan Kejadian Nyeri Punggung Bawah Pada Pasien Rawat Jalan di Poli klinik Saraf RSUD Dokter Soedarso Pontianak. Jurnal 
Jurnal Kesehatan Masyarakat \& Gizi, e-ISSN: 2655-0849

Vol.4 No.1 Edisi Mei-Oktober 2021

https://ejournal.medistra.ac.id/index.php/JKG

Received: 29 Agustus 2021 :: Accepted: 13 Oktober 2021 :: Published: 31 Oktober 2021

Mahasiswa PSPD Universitas

Tanjung pura, 1(1): 1-15.

Lase, E. H., (2015). Pengaruh Kompres Jahe Terhadap Intensitas nyeri pada Penderita Heumathoid Arthritis Usia 40 Tahun Ke Atas di Lingkungan Puskesmas Tiga Balata. Fakultas keperawatan Dan Kebidanan Sari Mutiara Indonesia

Natosba, Jaji , Pengaruh Posisi Ergonomis Terhadap Kejadian Low Back Pain Pada Penenun Songket di Kampung BNI 46.

Umami A.R., Hartanti R.I., \& Dewi P.S. 2014. Hubungan Antara Karakteristik Responden dan Sikap Kerja Duduk Dengan Keluhan Nyeri Punggung Bawah (Low Back Pain) pada Pekerjaa Batik Tulis. E-Jurnal Pustaka Kesehatan, vol. 2,, No. 1. Pp. 7278

Payuk. K.L. Djajakusli R. Dan Wahyu A. (2013). Hubungan Faktor Ergonomi Dengan Beban Kerja Pada Petani Padi Tradisional Di Desa Congko Kecamatan Mariowawo Kabupaten Soppeng. Jurnal FKM UNHAS, Makasar.

World Health Organization. (2014). Low back Pain Priority Medicines For Europe And The World. 81 : 671. 6 . 